\title{
Effects of Angelicae dahuricae Radix on 2, 4-Dinitrochlorobenzene-Induced Atopic Dermatitis-Like Skin Lesions in mice model
}

\author{
Jin Mo Ku', Se Hyang Hong ${ }^{1}$, Hyo In Kim', Hye Sook Seo ${ }^{2}$, Yong Cheol Shin² and Seong-Gyu Ko ${ }^{2^{*}}$ (D)
}

\begin{abstract}
Background: Atopic dermatitis (AD) is an inflammatory, chronically relapsing, and intensively pruritic skin disease that affect $10-30 \%$ of the global population. Angelicae dahuricae Radix (ADR) has been reported to be antiinflammatory in Korean Medicine. In the present study, we investigated whether ADR suppresses the progression of $A D$ in animal model.

Methods: AD was induced by 2, 4-Dinitrochlorobenzene (DNCB). ADR was orally administered to mice to study the effect of ADR on AD. Histological Analysis, immunohistochemistry, blood analysis, RT-PCR, and ELISA assay were performed.

Results: ADR significantly suppressed AD-like symptoms in BALB/c mice: ADR decreased skin thickness and spleen weight of mice. ADR reduced infiltration of mast cells, inflammatory cells and CD4+ cells into mouse skin. ADR lowered the number of WBCs in the blood of mice. ADR reduced the levels of IgE, IL-6, IL-10 and IL-12 in mice serum. ADR down-regulated mRNA expression of IL-4, IL-6 and TNF-a in mouse skin tissue.
\end{abstract}

Conclusion: Our present study clearly indicates that ADR suppresses the progression of AD induced by DNCB in $B A L B / c$ mice. This suggests that ADR might be a useful drug for the treatment of AD.

Keywords: Atopic dermatitis, Angelicae dahuricae Radix, 2, 4-Dinitrocholrlbenzene, BALB/c mice, Cytokine, Inflammation

\section{Background}

$10-30 \%$ of the global population in the world suffer by atopic dermatitis (AD), which is also known as atopic eczema, and is one of the most common allergic diseases $[1,2]$. AD is characterized by chronic or relapsing skin disorder, skin barrier dysfunction, and pruritic skin inflammation [3-5]. $2-10 \%$ of adults and $15-30 \%$ of children suffer from AD experiencing a significant reduction in quality of life [6-8]. Over the past 10 years, the prevalence of $\mathrm{AD}$ has increased a two-fold in elementary school-aged children in South Korea [9]. Therefore, successful treatment of $\mathrm{AD}$ is a very important task to decline disease.

The pathogenesis of AD is not well known, but two main theories have been proposed. In one theory, it was

\footnotetext{
* Correspondence: epiko@khu.ac.kr

${ }^{2}$ Department of Preventive Medicine, College of Korean Medicine, Kyung Hee University, 1 Hoegi, Seoul 130-701, Korea

Full list of author information is available at the end of the article
}

explained that $\mathrm{AD}$ is associated with filaggrin gene mutations. Filaggrin is a filament-associated protein that binds to keratin fibers in epidermis. Defection in filaggrin seems to induce skin barrier dysfunction leading to water loss from the skin [10, 11]. The other theory is immunological hypothesis associated with Th1/Th2 imbalance. T-helper cells play an important role in disease onset and progression. There is a predominance of Th2 cells rather than Th1. This results in increased infiltration of inflammatory cells such as lymphocytes and macrophages into the skin lesions, and eosinophilia in peripheral blood. This also induces increased level of immunoglobulin E (IgE) $[12,13]$.

Surfaces of mast cells aggregate high-affinity IgE receptors (FceI). IgE secretion is an important immediate hypersensitivity reaction in $\mathrm{AD}$ through mast cells. Mast cell activation releases not only inflammatory mediators but also Th2 cytokines (IL-4, IL-5 and 
IL-13) $[14,15]$. Proinflammatory cytokines such as IL-6 and IL-10 play an important role in allergic inflammation $[16,17]$. Moreover, proliferation of CD4+ $\mathrm{T}$ cells is observed in AD patient [18-20].

Angelicae dahuricae Radix (ADR) is a perennial plant that grows naturally. ADR are commonly known as Chinese Angelica, Wild Angelica, or Bai Zhi in Chinese [21]. ADR is known as Baig-Ji in Korean. ADR leaves are used to make strong scented incense. In addition, ADR are used in traditional medicine to counter harmful external influences on the skin, such as cold, headaches, rhinitis, heat, dampness and dryness [22]. In the experimental study, ADR alleviated the redness, swelling, and other symptoms of acute inflammation in mouse and rat [23]. ADR reduced the levels of the serum inflammatory mediators including Nitric oxide (NO), Tumor Necrosis Factor-alpha (TNF- $\alpha$ ), and prostaglandid E2 (PGE2) [24]. ADR showed anti-inflammatory activity in RAW264.7 cell and cytotoxic effect in A549 cells and KB cells [25]. Main compound of ADR is known to be an aviprin [26]. Aviprin showed antioxidant activity and is cytotoxic on LNCaP and HeLa cell lines [27]. These results indicate that ADR may be good candidate for the control of $\mathrm{AD}$ and beneficial in the treatment of human allergic disorders.

In the present study, we investigated whether ADR oral administration has anti-inflammatory activity on 2,4-dinitrochlorobenzene-(DNCB-) induced AD-like skin lesions in mice model.

\section{Methods}

\section{Preparation of Angelicae dahuricae Radix (ADR)}

ADR was supplied by Han-poong Pharm Co., Ltd (Jeonjoo, Republic of Korea). ADR powder was dissolved in distilled water to give to mice a concentration of $200 \mathrm{mg} / \mathrm{kg}$.

\section{Animals}

Animal experiments were approved by Kyung Hee university institutional animal care of use committee (KHUASP(SE)) and performed according to ethical treatment. Six-week-old male BALB/c mice were purchased from Orient (Seoul, Republic of Korea). Mice were maintained for 1 week before the start of the experiment. Animals were randomized and all housed under controlled temperature $\left(23 \pm 3{ }^{\circ} \mathrm{C}\right)$ and humidity (55 $\pm 15 \%)$, with a $12 \mathrm{~h}$ light $/ 12 \mathrm{~h}$ dark cycle. Animals were provided with a laboratory diet and water ad libitum. Body weight and Food intake of animals were measured once every 2 days.

\section{Induction of $A D$ and treatment}

Induction of $\mathrm{AD}$ procedure and treatment are described in Fig. 1. The mice were divided into three groups $(n=8)$ : group 1, normal; group 2, DNCB; group $3, \mathrm{DNCB}+$ $\operatorname{ADR}(200 \mathrm{mg} / \mathrm{kg})$. For the experiment, mice back skin was painted dermally with $200 \mu \mathrm{L}$ of a $2 \%$ DNCB using $1 \times 1 \mathrm{~cm}$ patches after shaving. Three weeks after sensitization, the back skin was challenged with $200 \mu \mathrm{L}$ of a $0.2 \%$ DNCB solution. Finally, mice were fed with ADR together with DNCB sensitiazation for 2 weeks. At the end of experiment, mice were sacrificed by $\mathrm{CO}_{2}$ inhalation, and samples were collected.

\section{Histological Analysis}

Skin samples were embedded in Tissue-Tek optical cutting temperature (OCT) compound (Leica, USA). The section of the skin samples was $20 \mu \mathrm{m}$-thick. We used caliper to measure skin thickness. Each section was stained with hematoxylin and eosin ( $\mathrm{H} \& \mathrm{E})$ for inflammatory cells and with toluidine blue (T.B) for mast cells, and examined under light microscopy (Olympus). Mast cells and inflammatory cells were counted in 10 parts of high-power fields (HPF) $(250 \mu \mathrm{m} x 250 \mu \mathrm{m})$ at 40x, 400x and 1000x magnification.

\section{Immunohistochemistry}

Expression of CD4+ lymphocytes was detected by immunohistochemical analysis using the anti-CD4+ antibody. The skin tissues were rehydrated. After a microwave treatment, the sections were treated with $3 \%$ hydrogen peroxide in PBS for 15 min to inhibit endogenous peroxidase activity of blood cells. The skin sections were blocked with 5\% bovine serum albumin (BSA) in PBS for $1 \mathrm{~h}$, at room temperature. Skin sections were incubated with mouse monoclonal $\mathrm{CD} 4+$ antibody overnight at $4{ }^{\circ} \mathrm{C}$ and subsequently incubated with secondary biotinylated antirabbit IgG for $1 \mathrm{~h}$ at room temperature. Sections were treated with avidin-biotin HRP complex (Vectastain ABC

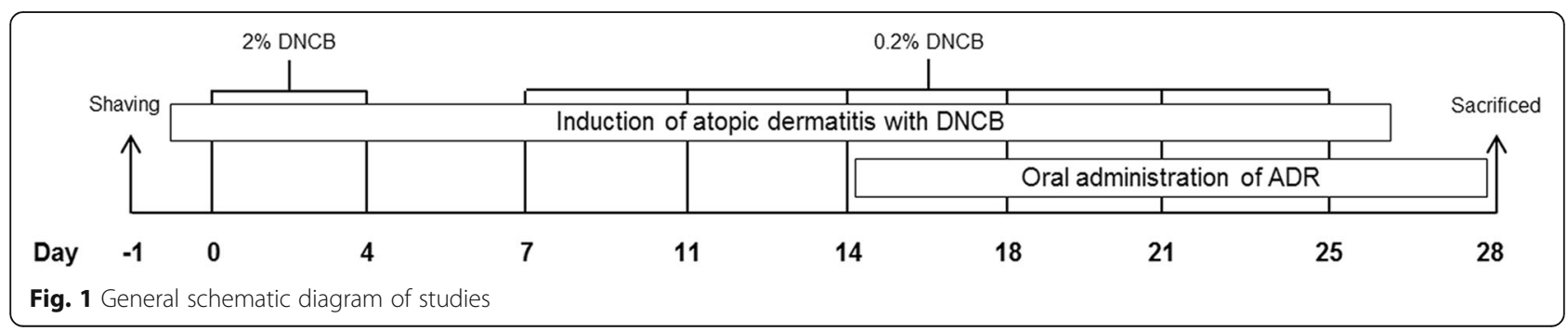


kit, Vector Labs, Burlingame, CA, USA) for $30 \mathrm{~min}$ at $4{ }^{\circ} \mathrm{C}$ and finally stained with diaminobenzidine tetrachloride (DAB) as a substrate. The slides were mounted with an aqueous mounting solution (DAKO, Glostrup, Denmark) and cover-slipped. All the sections were analyzed using an Olympus microscope and images were captured using a digital video camera.

\section{Analysis of mouse blood}

Whole blood samples were collected by cardiac puncture. The blood was placed in Vacutainer TM tubes containing EDTA (BD science, Franklin Lakes, NJ, USA). Anti-coagulated blood was submitted to determination of hematological parameters (WBC, lymphocytes, monocytes, eosinophils, basophils and neutrophils) in a HEMAVET 950 hematology analyzer (Drew Scientific, Inc., Miami Lakes, FL, USA) in accordance to manufacturer' recommendation.

\section{RT-PCR}

RNA was isolated using easy-blue RNA extraction kit (iNtRON biotech, Seongnam, Republic of Korea) according to the manufacturer's instructions. Isolated RNA content was measured using the NanoDrop ND-1000 spectrophotometer (NanoDrop Technologies Inc, Wilmington, North Carolina, USA). Total cellular RNA from each sample was reversely transcribed using cDNA synthesis kit (TaKaRa, Otsu, Shiga, Japan). PCR was performed using the specific primer. The primers used were as follows : mouse IL-4 (Forward : 5' - TCG GCA TTT TGA ACG AGG TC - 3', Reverse : 5' - GAA AAG CCC GAA AGA GTC TC - 3'); mouse IL-6 (Forward : 5' - GAT GCT ACC AAA CTG GAT ATA ATC - 3', Reverse : 5' GGT CCT TAG CCA CTC CTT CTG TG - 3'); mouse TNF- $\alpha$ (Forward : 5' - ATG AGC ACA GAA AGC ATG ATC - 3', Reverse : 5' - TAC AGG CTT GTC ACT GGA ATT - 3'); and mouse GAPDH (Forward : 5' - GAG GGG
CCA TCC ACA GTC TTC - 3', Reverse : 5' - CAT CAC CAT CTT CCA GGA GCG - 3').

\section{Enzyme-Linked Immune Sorbent Assay (ELISA)}

For measurement of total serum IgE, IL-6, IL-10 and IL12, blood specimens were obtained from the heart on the final day. The blood was placed in Vacutainer tubes containing EDTA (BD science, Franklin Lakes, NJ, USA) and blood plasma was isolated. Total IgE, IL-6, IL-10 and IL-12 levels in plasma were determined by sandwich ELISA using the BD PharMingen ELISA set according to the manufacturer's instruction. Optical densities were measured at $450 \mathrm{~nm}$ using a microplate reader (Versa Max, Molecular Devices, Sunnyvale, CA, USA).

\section{Statistical analysis}

All quantitative data derived from this study were analyzed statistically. One-way ANOVA was used for analysis of our data. The results were expressed as the mean \pm SEM. Statistical significance at $P<0.05<0.01$ and $<0.001$ has been given respective symbols in the figures.

\section{Results}

Effect of oral administration of ADR on body weight and food intake of mice

We monitored body weight and food intake of mice throughout the study. We observed no significant changes in this regard, indicating that ADR may not affect general conditions in mice (Fig. 2a and b).

\section{Effect of ADR on DNCB-induced AD in mice model}

$\mathrm{AD}$-like skin lesions were induced in Balb/c mice applying DNCB for 4 weeks. DNCB application was followed by ADR oral administration. ADR markedly inhibited $\mathrm{AD}$ as shown in Fig. 3a. A histogram of skin thickness estimated is shown in Fig. 3b. Normal skin was found to be $0.58 \pm 0.12 \mathrm{~mm}$ (ranging from 0.46 to $0.84 \mathrm{~mm}$ ), while DNCB-induced AD skin (negative control) was found to

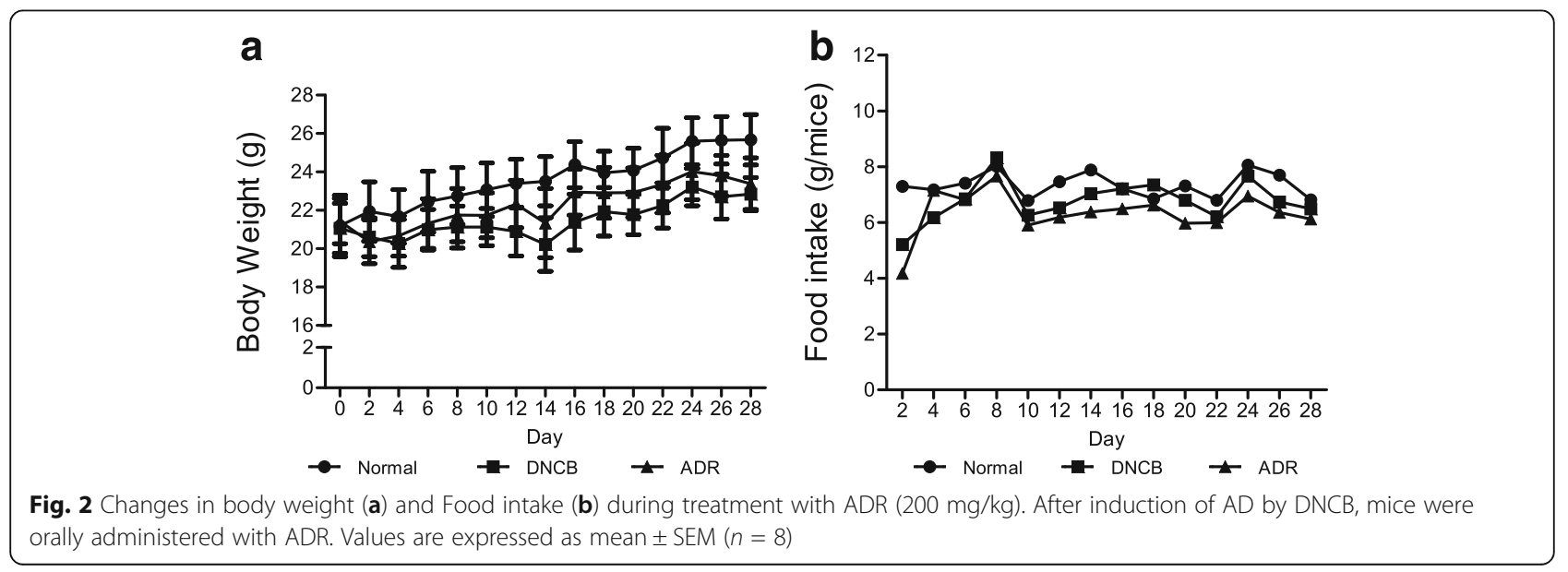



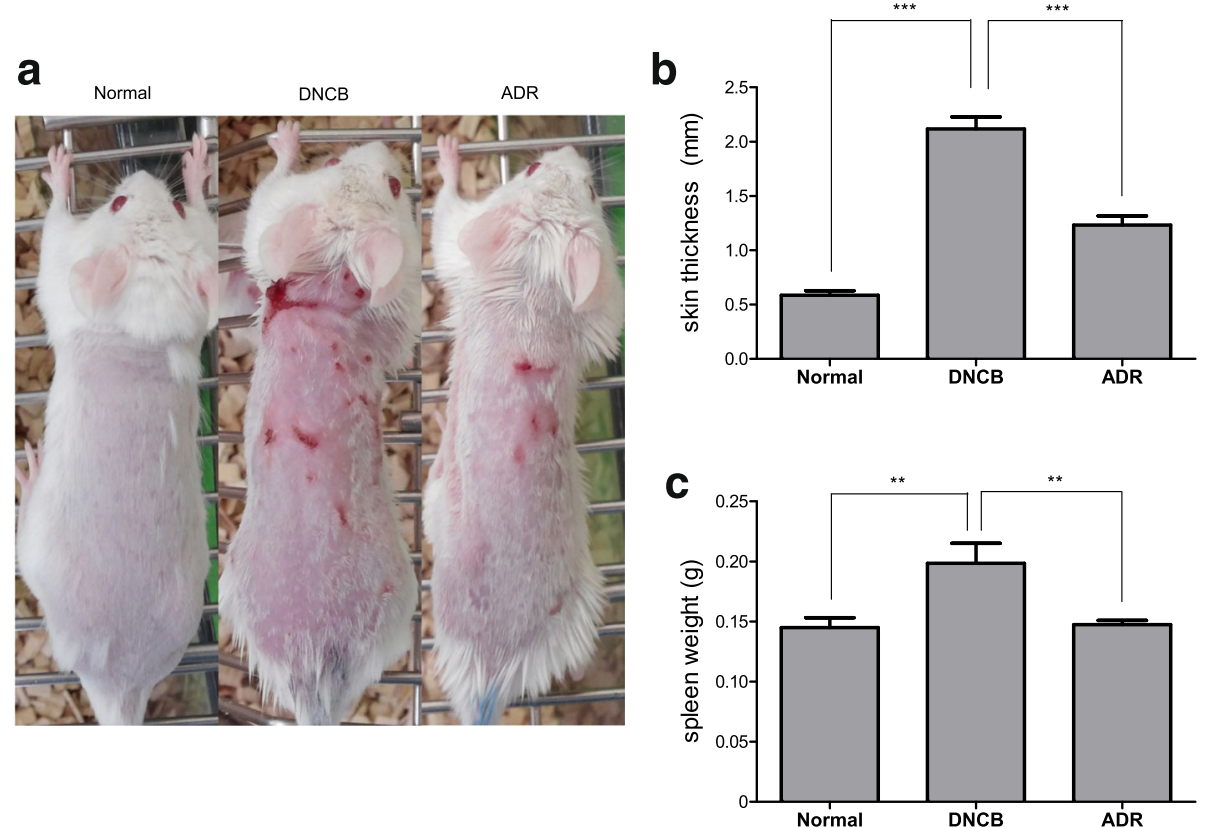

Fig. 3 Observations of skin lesions in ADR (200 mg/kg) treated DNCB-induced AD mice. The photograph shows the back of mice on day 28 after sensitization (a). The measurement of skin thickness (b) spleen weight (c) in DNCB-induced AD mice model treated with ADR. Values are expressed as mean $\pm \operatorname{SEM}(n=8)$

be $2.12 \pm 0.27 \mathrm{~mm}$ (ranged from 1.92 to $2.66 \mathrm{~mm}$ ). DNCBinduced AD skin orally treated with ADR was found to be $1.23 \pm 0.21 \mathrm{~mm}$ (ranged from 0.92 to $1.48 \mathrm{~mm}$ ). Data demonstrate that ADR decreased skin thickness of mice. Moreover, ADR decreased spleen weight of mice (Fig. 3b).

\section{Effect of ADR on mast cells, inflammatory cells and CD4+ cells}

To determine whether ADR reduces infiltration of mast cells and inflammatory cells into skin, we performed $\mathrm{T}$ \& $B$ staining and $\mathrm{H}$ \& $\mathrm{E}$ staining on the skin samples. Numbers of mast cells and inflammatory cells in AD mice were shown to be higher than those in normal mice. ADR decreased such infiltration of mast cells and inflammatory cells into skin (Fig. 4a, c). Mast cells and inflammatory cells numbers under each condition were shown in Fig. 4b, d. We performed immunocytochemistry to examine whether ADR reduces level of CD4+ (total T cells) within skin. The level of CD4+ in DNCB-induced $\mathrm{AD}$ lesions in mice is higher than that in normal mice. ADR decreased the level of CD4+ cells within the skin (Fig. 4e, f).

\section{Effect of ADR on WBCs in the blood of mice}

To investigate whether ADR suppresses inflammatory phenomenon, we measured leukocytes levels in cardiovascular blood samples using HEMAVET 950 hematology analyzer. We observed that DNCB application increased total number of white blood cells (WBCs) and each subtypes of WBCs including neutrophils, basophils, eosinophils, monocytes, and lymphocytes in serum of mice. Importantly, a subsequent oral administration of ADR lowered the increased number of WBCs, implicating ADR suppresses inflammatory responses by decreasing the number of WBCs in the blood (Fig. 5a, b, c, d, e and $\mathrm{f}$ ).

Effect of ADR on the levels of IgE, IL-6, IL-10 and IL-12 in mice serum

We measured the levels of inflammatory cytokines in the blood samples by ELISA assay.

We found that DNCB increased the levels of IgE, IL-6, IL-10 and IL-12 while ADR inhibited such increases (Fig. 6a, b, c and d).

\section{Effect of ADR on mRNA expression of IL-4, IL-6 and TNF- $a$} in mouse skin tissue

To determine whether ADR decreases AD-relevant cytokines expression, we performed RT-PCR to measure levels of IL-4, IL- 6 and TNF- $\alpha$. We found that DNCB increased the levels of IL-4, IL- 6 and TNF- $\alpha$ while ADR decreased such increases (Fig. 7a, b, c and d).

\section{Discussion}

$\mathrm{AD}$ is a chronic inflammatory skin disease, which increases serum immunoglobulin E (IgE) levels and infiltration of inflammatory cellincluding mast cells and eosinophils $[28,29]$. The pathogenesis of $\mathrm{AD}$ is primarily 


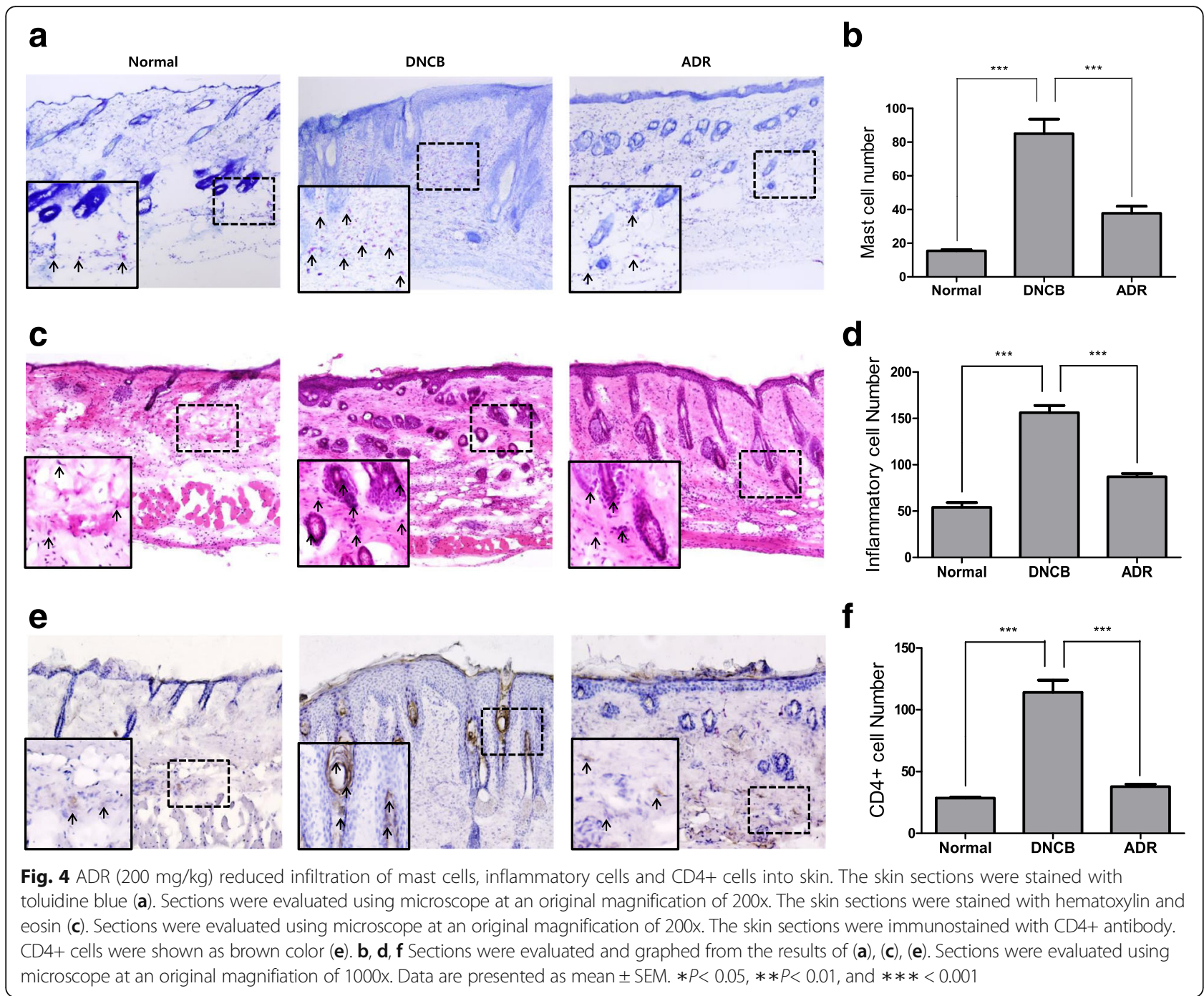

driven by Th2 immune responses [14]. This causes epidermal thickness of mice with cutaneous hypersensitivity.

CD4+ T cells and mast cells are known as key factors in allergic inflammatory diseases. AD mouse model contains increased CD4+ T cell [30, 31]. DNCB-induced AD mouse model showed severe AD symptoms, increase in mast cells, epidermal hyperplasia and elevation of serum IgE levels. DNCB-induced BALB/c mice model represented increase of IL-4 mRNA level. BALB/c mouse is advantageous $\mathrm{AD}$ model as compared to other animal model since it develops Th2-skewed immune response [32, 33].

In this study, we investigated the anti-AD effects of ADR using DNCB-applied BALB/c mice. We found that oral administration of ADR strongly suppressed DNCBinduced $\mathrm{AD}$-like symptoms such as skin thickness. Normal skin was found to be $0.58 \pm 0.12 \mathrm{~mm}$ (ranging from 0.46 to $0.84 \mathrm{~mm}$ ), while DNCB-induced AD skin (negative control) was found to be $2.12 \pm 0.27 \mathrm{~mm}$ (ranged from 1.92 to $2.66 \mathrm{~mm}$ ). DNCB- induced AD skin orally treated with ADR was found to be $1.23 \pm 0.21 \mathrm{~mm}$ (ranged from 0.92 to $1.48 \mathrm{~mm}$ ). ADR also reduced infiltration of mast cells, inflammatory cells and CD4+ cells into the sensitized skin. Numbers of mast cells and inflammatory cells in AD mice were shown to be higher than those in normal mice. ADR decreased such infiltration of mast cells and inflammatory cells into skin. The level of CD4+ in DNCB-induced AD lesions in mice is higher than that in normal mice. ADR decreased the level of CD4+ cells within the skin

In $\mathrm{AD}$ skin, activated Th2 cells would produce IgE by releasing cytokines such as IL-4 [34, 35]. Associated Th2 inflammatory cytokine, such as IL-4 and IL- 6 could promote the occurrence and development of inflammatory reactions [19, 36, 37]. In our study, ADR application decreased the serum levels of IgE, IL-6, IL-10 and IL-12 that are induced by DNCB treatment. DNCB increased the levels of IgE, IL-6, IL-10 and IL-12 while ADR 


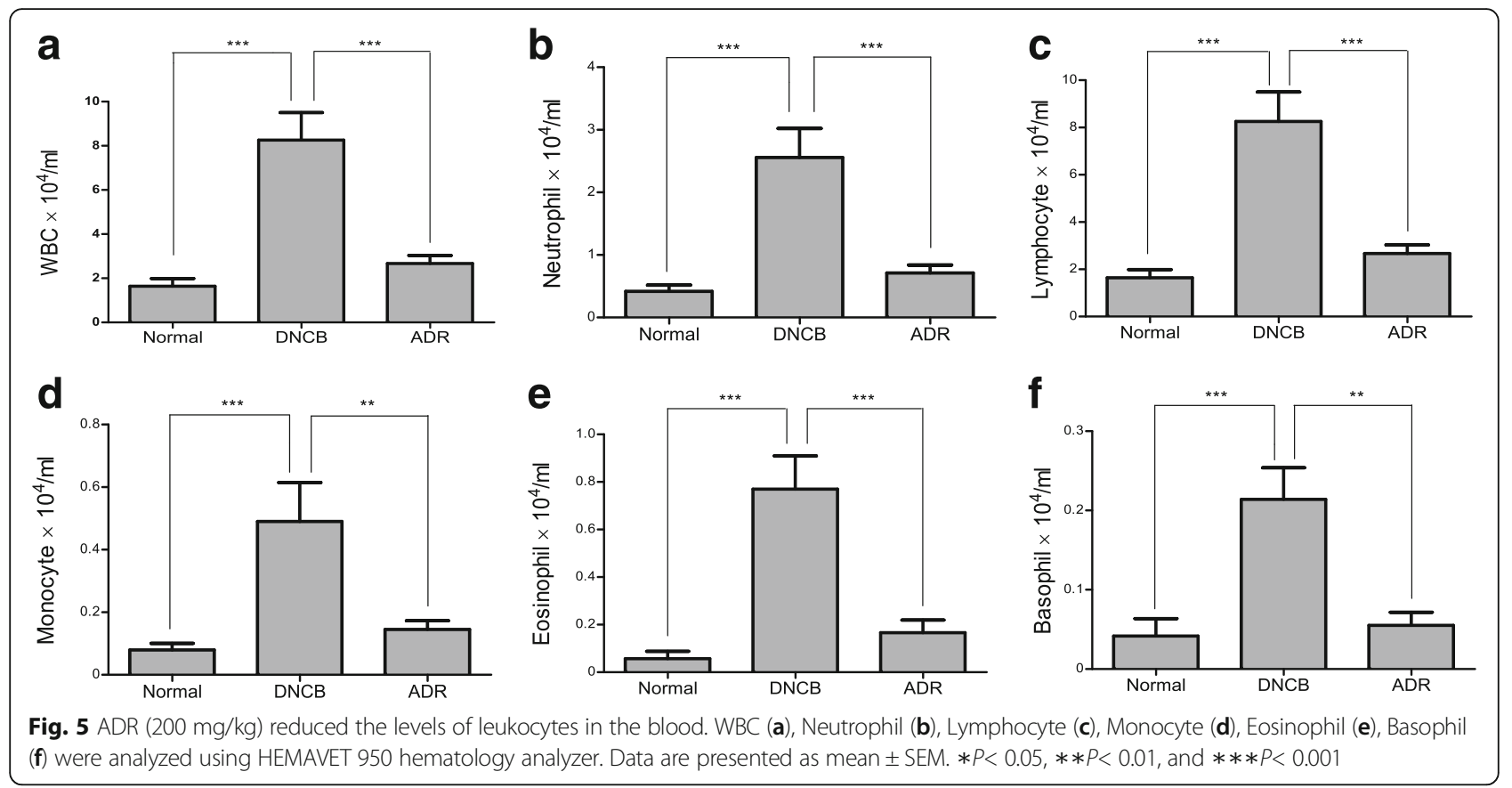

inhibited such increases. ADR application reduced the DNCB-stimulated increases of the number of eosinophils, neutrophils, monocytes, basophils, lymphocytes and WBC. A subsequent oral administration of ADR lowered the increased number of WBCs, implicating ADR suppresses inflammatory responses by decreasing the number of WBCs in the blood Moreover, ADR reduced the levels of IL-4, IL- 6 and TNF- $\alpha$ mRNA expression. ADR exhibited decrease in mast cell recruitment and serum IgE levels. ADR reduced infiltration of CD4+ cells into mouse skin. ADR suppressed the expression of inflammatory cytokine including IL-4, IL-6, IL-10 and TNF- $\alpha$. DNCB increased the levels of IL-4, IL- 6 and TNF- $\alpha$ while ADR decreased such increases.

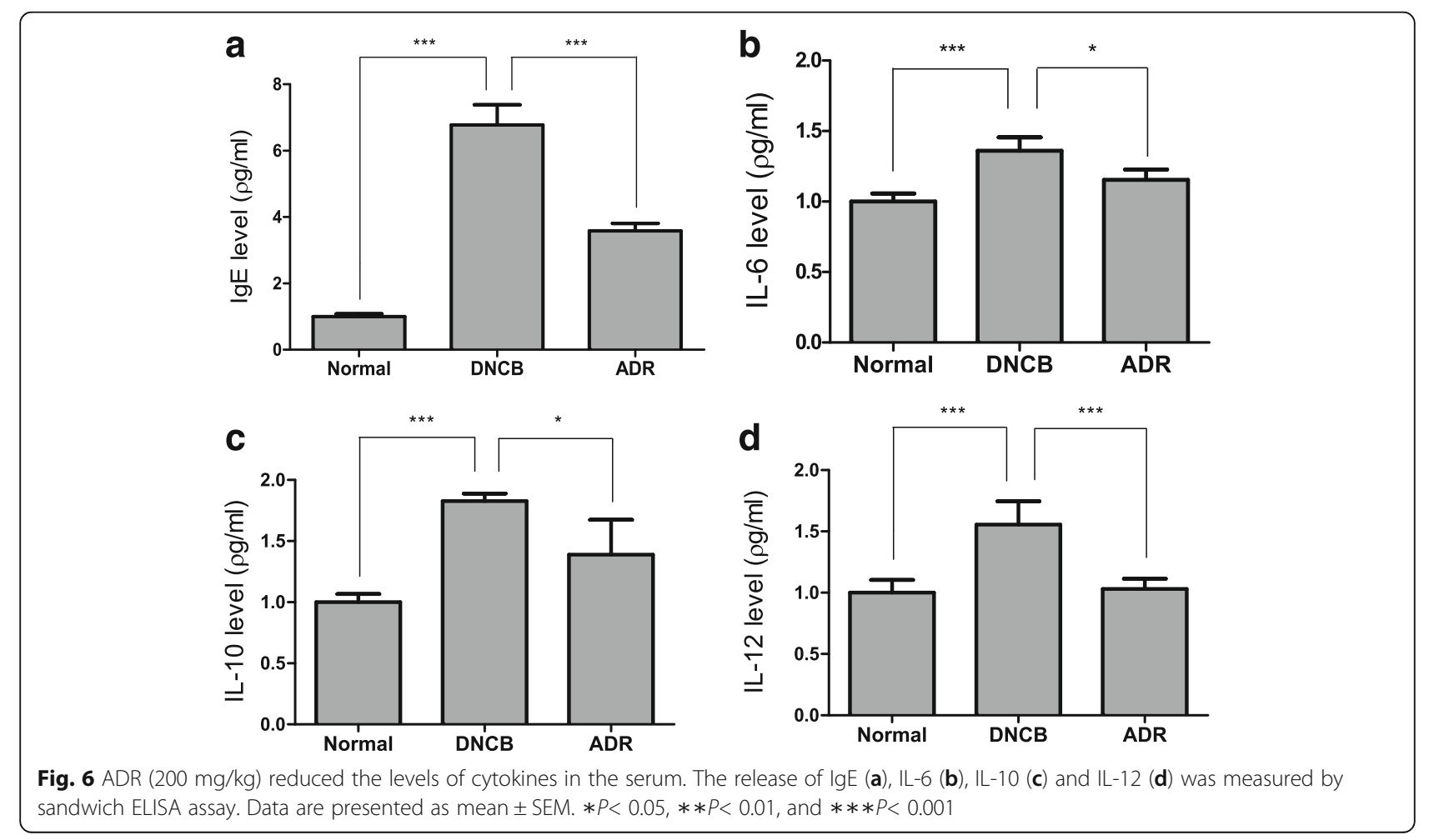



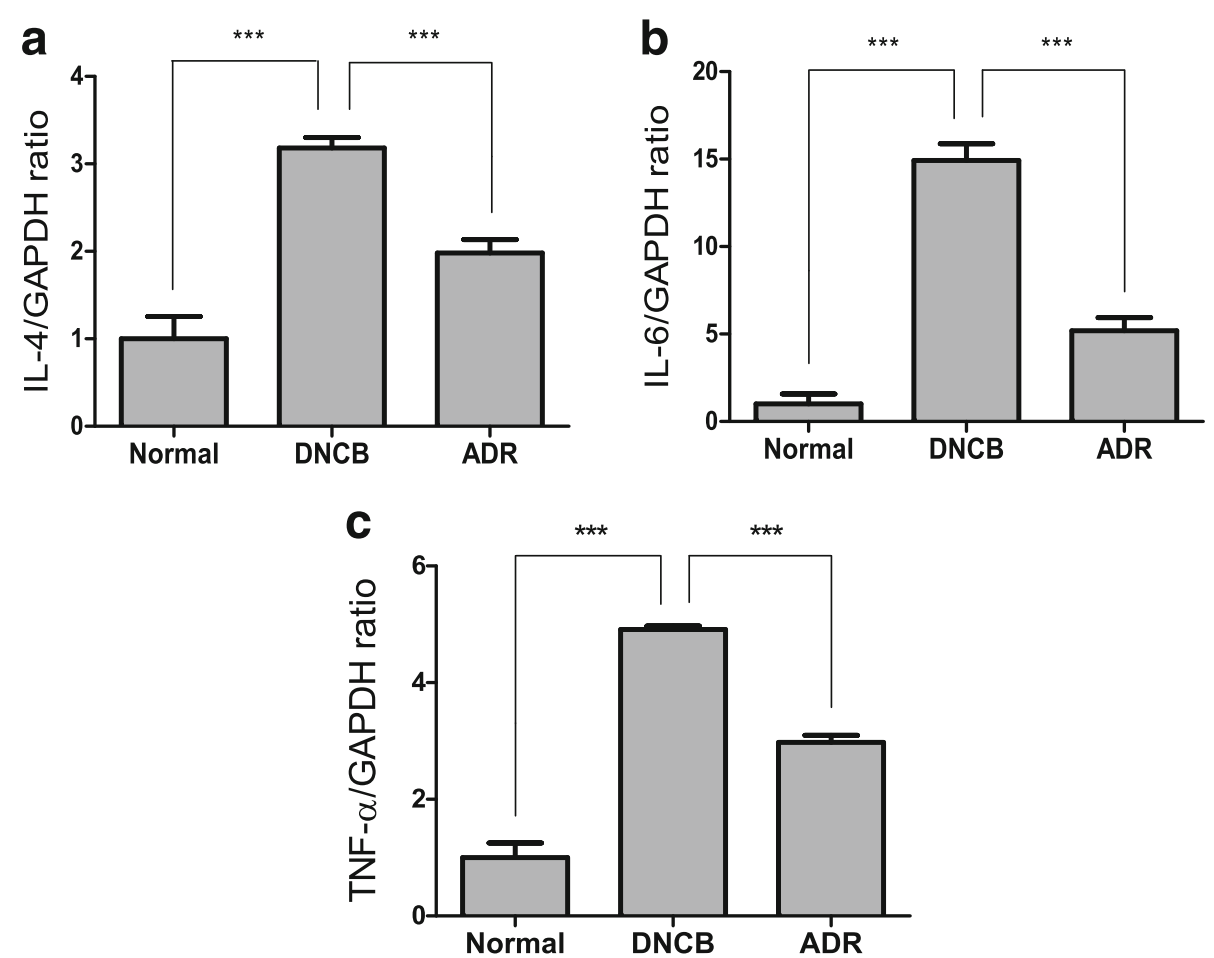

Fig. 7 Effect of ADR (200 mg/kg) on the cytokine mRNA expression in mouse skin tissue. The IL-4, IL-6 and TNF-a mRNA expression were measured by RT-PCR (a), (b), (c) in mouse skin tissue. The columns and the error bars represent mean \pm SD ( $n=8$ mice/group). $* P<0.05, * * P<0.01$, and $* * *<0.001$

These results suggest that ADR suppresses skin inflammation by inhibiting the DNCB-stimulated numerous inflammatory responses. Moreover, free radicals are unstable and independent but can be cause of many diseases including cancer and atopic dermatitis. ADR seems to act against free radicals by removing them [38, 39] Limitations of AD model is that animal study generates many differences from human study in terms of the anatomical, physiological, and immunological contributors. Moreover, it is difficult to establish chronic disease model in mice. Nevertheless, AD mice model is still important tool to investigate chronic disease for human being.

\section{Conclusions}

Our present study clearly demonstrates that ADR suppresses the progression of $\mathrm{AD}$ induced by $\mathrm{DNCB}$. ADR significantly suppressed AD-like symptoms in BALB/c mice: ADR decreased skin thickness and spleen weight of mice. ADR reduced infiltration of mast cells, inflammatory cells and CD4+ cells into mouse skin. ADR lowered the number of WBCs in the blood of mice. ADR reduced the levels of IgE, IL-6, IL-10 and IL-12 in mice serum. ADR down-regulated mRNA expression of IL-4, IL- 6 and TNF- $\alpha$ in mouse skin tissue. Therefore, ADR might be a useful drug for the treatment of AD. Our data indicates that ADR have a potential as a new drug for the suppression of $\mathrm{AD}$.
Acknowledgments

This work was supported by a grant from Korean Medicine R\&D Project of the Ministry of Health and Welfare (H112C1889 and HI13C0530).

\section{Availability of data and materials}

All data and materials are contained and described within the manuscript.

Authors' contributions

JMK carried out the experiment and drafting of manuscript. SHH and HIK revised the research and manuscript and assisted in the research work. HSS and YCS guided the research, revised and submitted the manuscript. S-GK supervised the research. All the authors read and approved the final manuscript.

\section{Competing interests}

The authors declare that they have no competing interest.

\section{Consent for publication}

This section is not applicable in this research.

\section{Ethics approval}

Animal experiments were approved by Kyung Hee university institutional animal care of use committee (Approval No. KHUASP(SE)-12-014).

\section{Author details}

${ }^{1}$ Department of Science in Korean Medicine, Graduate School, Kyung Hee University, Seoul 02447, Korea. ${ }^{2}$ Department of Preventive Medicine, College of Korean Medicine, Kyung Hee University, 1 Hoegi, Seoul 130-701, Korea.

Received: 5 August 2016 Accepted: 14 January 2017

Published online: 07 February 2017

\section{References}

1. Ring J, Alomar A, Bieber T, Deleuran M, Fink-Wagner A, Gelmetti C, Gieler U, Lipozencic J, Luger T, Oranje AP, et al. Guidelines for treatment of 
atopic eczema (atopic dermatitis) part I. J Eur Acad Dermatol Venereol. 2012;26(8):1045-60.

2. Ring J, Alomar A, Bieber T, Deleuran M, Fink-Wagner A, Gelmetti C, Gieler U, Lipozencic J, Luger T, Oranje AP, et al. Guidelines for treatment of atopic eczema (atopic dermatitis) Part II. J Eur Acad Dermatol Venereol. 2012;26(9):1176-93.

3. Spergel JM, Paller AS. Atopic dermatitis and the atopic march. J Allergy Clin Immunol. 2003;112(6 Suppl):S118-127.

4. Boguniewicz $M$, Leung DY. Recent insights into atopic dermatitis and implications for management of infectious complications. J Allergy Clin Immunol. 2010;125(1):4-13. quiz 14-15.

5. Vale S, Smith J, Paterson T, Bramah S, Butt C. Australasian Society of Clinical Immunology and Allergy (ASCIA) 26th Annual Conference, 9-12 September 2015, Adelaide, Australia. Intern Med J. 2015;45(Suppl 4):1-30.

6. Williams H, Stewart A, von Mutius E, Cookson W, Anderson HR. Is eczema really on the increase worldwide? J Allergy Clin Immunol. 2008;121(4):947-54. e915.

7. Williams H, Flohr C. How epidemiology has challenged 3 prevailing concepts about atopic dermatitis. J Allergy Clin Immunol. 2006;118(1):209-13.

8. Bieber T. Atopic dermatitis. N Engl J Med. 2008;358(14):1483-94.

9. Lee SI, Kim J, Han Y, Ahn K. A proposal: Atopic Dermatitis Organizer (ADO) guideline for children. Asia Pac Allergy. 2011;1(2):53-63.

10. Wolff K, Johnson RA, Fitzpatrick TB. Fitzpatrick's color atlas and synopsis of clinical dermatology. 6th ed. New York: McGraw-Hill Medical; 2009.

11. Maintz L, Novak N. Getting more and more complex: the pathophysiology of atopic eczema. Eur J Dermatol. 2007;17(4):267-83.

12. Thomsen SF. Atopic dermatitis: natural history, diagnosis, and treatment. ISRN Allergy. 2014;2014:354250.

13. Stone SP, Gleich GJ, Muller SA. Atopic dermatitis and IgE. Relationship between changes in IgE levels and severity of disease. Arch Dermatol. 1976; 112(9):1254-5.

14. Brandt EB, Sivaprasad U. Th2 Cytokines and Atopic Dermatitis. J Clin Cell Immunol. 2011;2(3):110.

15. Nedoszytko B, Sokolowska-Wojdylo M, Ruckemann-Dziurdzinska K, Roszkiewicz J, Nowicki RJ. Chemokines and cytokines network in the pathogenesis of the inflammatory skin diseases: atopic dermatitis, psoriasis and skin mastocytosis. Postepy Dermatol Alergol. 2014;31(2):84-91.

16. Sprague $\mathrm{AH}$, Khalil RA. Inflammatory cytokines in vascular dysfunction and vascular disease. Biochem Pharmacol. 2009;78(6):539-52.

17. Wong CK, Ho CY, Ko FW, Chan CH, Ho AS, Hui DS, Lam CW. Proinflammatory cytokines (IL-17, IL-6, IL-18 and IL-12) and Th cytokines (IFN-gamma, IL-4, IL-10 and IL-13) in patients with allergic asthma. Clin Exp Immunol. 2001;125(2):177-83.

18. Bradding P, Feather $\mathrm{H}$, Wilson S, Bardin PG, Heusser CH, Holgate ST, Howarth $\mathrm{PH}$. Immunolocalization of cytokines in the nasal mucosa of normal and perennial rhinitic subjects. The mast cell as a source of IL-4, IL-5, and IL-6 in human allergic mucosal inflammation. J Immunol. 1993;151(7):3853-65.

19. Mican JA, Arora N, Burd PR, Metcalfe DD. Passive cutaneous anaphylaxis in mouse skin is associated with local accumulation of interleukin-6 mRNA and immunoreactive interleukin-6 protein. J Allergy Clin Immunol. 1992;90(5):815-24.

20. Laborel-Preneron E, Bianchi P, Boralevi F, Lehours P, Fraysse F, Morice-Picard F, Sugai M, Sato'o Y, Badiou C, Lina G, et al. Effects of the Staphylococcus aureus and Staphylococcus epidermidis Secretomes Isolated from the Skin Microbiota of Atopic Children on CD4+ T Cell Activation. PLoS One. 2015;10(10):e0141067.

21. Sarker SD, Nahar L. Natural medicine: the genus Angelica. Curr Med Chem. 2004;11(11):1479-500.

22. Chevallier A. Encyclopedia of herbal medicine (book review). Libr J. 2001;126(5):70.

23. Lee H, Lee JK, Ha H, Lee MY, Seo CS, Shin HK. Angelicae dahuricae Radix inhibits dust mite extract-induced atopic dermatitis-like skin lesions in NC/ Nga mice. Evid Based Complement Alternat Med. 2012;2012:743075.

24. Wang C, Sun J, Li H, Yang X, Liu H, Chen J. In vivo anti-inflammatory activities of the essential oil from Radix Angelicae dahuricae. J Nat Med. 2016;70(3):563-70.

25. Wang MH, Jeong SH, Guo H, Park JB. Anti-inflammatory and cytotoxic effects of methanol, ethanol, and water extracts of Angelicae dahuricae Radix. J Oral Sci. 2016;58(1):125-31.

26. $\mathrm{Oh} \mathrm{H}$, Lee HS, Kim T, Chai KY, Chung HT, Kwon TO, Jun JY, Jeong OS, Kim YC, Yun YG. Furocoumarins from Angelica dahurica with hepatoprotective activity on tacrine-induced cytotoxicity in Hep G2 cells. Planta Med. 2002; 68(5):463-4
27. Zahri S, Razavi SM, Moatamed Z. Antioxidant activity and cytotoxic effect of aviprin and aviprin-3"-O-D-glucopyranoside on LNCaP and HeLa cell lines. Nat Prod Res. 2012;26(6):540-7.

28. Karuppagounder $\mathrm{V}$, Arumugam $\mathrm{S}$, Thandavarayan RA, Pitchaimani $\mathrm{V}$, Sreedhar R, Afrin R, Harima M, Suzuki H, Nomoto M, Miyashita S, et al. Tannic acid modulates NFkappaB signaling pathway and skin inflammation in NC/Nga mice through PPARgamma expression. Cytokine. 2015;76(2):206-13.

29. Liu FT, Goodarzi H, Chen HY. IgE, mast cells, and eosinophils in atopic dermatitis. Clin Rev Allergy Immunol. 2011;41(3):298-310.

30. Hershey GK, Friedrich MF, Esswein LA, Thomas ML, Chatila TA. The association of atopy with a gain-of-function mutation in the alpha subunit of the interleukin-4 receptor. N Engl J Med. 1997;337(24):1720-5.

31. Lee JH, Lee YS, Lee EJ, Kim TY. Capsiate Inhibits DNFB-Induced Atopic Dermatitis in NC/Nga Mice through Mast Cell and CD4+ T-Cell Inactivation. J Invest Dermatol. 2015;135(8):1977-85.

32. Kim IS, Lee NR, Baek SY, Kim EJ, Kim JS, Jeong TS, Shin DH, Park HY, Lee JS. Inhibitory effect of arazyme on the development of atopic dermatitis-like lesions in BALB/C and Nc/Nga mice. Mol Med Rep. 2015;11(5):3995-4001.

33. Yoon HJ, Jang MS, Kim HW, Song DU, Nam KI, Bae CS, Kim SJ, Lee SR, Ku CS, Jang DI, et al. Protective effect of diet supplemented with rice prolamin extract against DNCB-induced atopic dermatitis in BALB/C mice. BMC Complement Altern Med. 2015;15:353.

34. Lipozencic J, Pastar Z, Kulisic SM, Pavic I. Immunologic aspects of atopic dermatitis. Acta Dermatovenerol Croat. 2009;17(3):226-34.

35. Song Z, Deng X, Chen W, Xu J, Chen S, Zhong H, Hao F. Toll-like receptor 2 agonist Pam3CSK4 up-regulates FcepsilonRI receptor expression on monocytes from patients with severe extrinsic atopic dermatitis. J Eur Acad Dermatol Venereol. 2015;29(11):2169-76.

36. Dantas-Barbosa C, Brigido MM, Maranhao AQ. Construction of a human Fab phage display library from antibody repertoires of osteosarcoma patients. Genet Mol Res. 2005;4(2):126-40.

37. Micheal S, Minhas K, Ishaque M, Ahmed F, Ahmed A. IL-4 gene polymorphisms and their association with atopic asthma and allergic rhinitis in Pakistani patients. J Investig Allergol Clin Immunol. 2013;23(2):107-11.

38. Ayaz M, Junaid M, Ahmed J, Ullah F, Sadiq A, Ahmad S, Imran M. Phenolic contents, antioxidant and anticholinesterase potentials of crude extract, subsequent fractions and crude saponins from Polygonum hydropiper $\mathrm{L}$. BMC Complement Altern Med. 2014;14:145.

39. Ahmad S, Ullah F, Ayaz M, Sadiq A, Imran M. Antioxidant and anticholinesterase investigations of Rumex hastatus D. Don: potential effectiveness in oxidative stress and neurological disorders. Biol Res. 2015;48:20.

\section{Submit your next manuscript to BioMed Central and we will help you at every step:}

- We accept pre-submission inquiries

- Our selector tool helps you to find the most relevant journal

- We provide round the clock customer support

- Convenient online submission

- Thorough peer review

- Inclusion in PubMed and all major indexing services

- Maximum visibility for your research

Submit your manuscript at www.biomedcentral.com/submit 